\title{
錠剤の硬度および崩壊度の吸湿による経日変化*1
}

\author{
川影逸郎, 林 弘祐, 高取吉太郎*2 \\ 名古屋大学医学部付属病院薬㓮部*2
}

\section{Effect of Humidity on Hardness and Disintegration Time of Tablets*1}

\author{
ITSURO KAWAKAGE, HIROSUKE HAYASHI, KICHITARO TAKATORI*2 \\ Pharmacy of Nagoya University Hospital*2
}

\begin{abstract}
Effect of humidity on hardness and disintegration time was examined on 25 kinds of uncoated tablets. Depending on the humidity in storage, hardness of the tablets changed in the following three patterns : (1) Larger in relative humidity $(\mathrm{RH})$ of $30-50 \%$ than in drier state, but smaller in $\mathrm{RH}$ more than $75 \%$. (2) No marked change in dry state and in RH up to $30-50 \%$, but smaller in $\mathrm{RH}$ more than $75 \%$. (3) Largest in dry state, and smaller as humidity increases.

Tablets were prevented from being moistened in low humidity, but not in high humidity. The effect of humidity on disintegration which occurred within one minute was not noted, since the disintegration time was too short. The disintegration time was reduced in 1 of 5 kinds of tablets which disintegrated in 1-2 min,1 of 4 in 2-3 min, all of 4 in 3-5 min, and 1 of 2 in $9-11 \mathrm{~min}$.
\end{abstract}

近年, 病院薬局の調剂において，錠剂の占める割合は 非常に多くなってきた.これにともない錠昘の品質管理 の重要性む增し, 重量偏差 ${ }^{1)}$, あるいは外観の変化 ${ }^{2)} に$ よる管理など種々な方法による錠凧の品質管理について 報告され，また実際各病院により実情にそくした管理方 法が行われているのが現状である.

われわれは今回，調剂され患者に交付された錠剤がそ の保管法によって，とくに保管中の湿度によってどのよ らな変化を受けるかについて検討した．錠剤の硬度と崩 壊度については結合剤, 滑沢剂などの添加剤による影

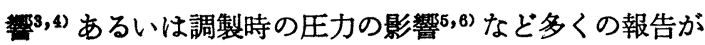
あり，また錠阂保存中の湿度による崩壊度の变化 ${ }^{7,8)}$ の報告もあるが，今回われわれは錟剤，とくに裸錠が保 存中の吸湿水分により硬度, 崩壊度にどのような影響を 受けるかについて検討したのでここに報告する.

\section{英 醶 の 部}

\section{1. 試料}

*1 日本薬学会第96年会(名古屋, 1976年 4 月)で発表.

*2 名古屋市昭和区鶴舞町65；65, Tsurumaicho, Showa-ku, Nagoya, 466 Japan
試料としては当院で使用している裸錠 25 種を選びそ の錠剂の同一ロット番号のものを試料とした.

\section{2. 硬度試跧}

各相対湿度 $(\mathrm{RH})$ Kシールのままの状態およびバラ 錠にして $23 \pm 1$ ○で14日間保存したのちの硬度の変化を 測定した。測定値はシールのままの状態拈よびバラ錠に したもの各々20鉸について測定しその平均值を求めた。 測定は萓垣製モンサント型硬度計を使用した。

\section{3. 崩填試瞔}

各相対湿度にシールのままの状態およびバラ錠にして $23 \pm 1^{\cup}$ で14日間保存したのちの崩壊時間の変化を 測定 した．測定値は各々 6 錠ずつ 3 回測定しその崩壊時間の 平均時間を示した。測定は 8 局規定の方法（補助盤使 用)により萓垣製崩壊試験器で測定した。

\section{4. 相対湿度}

無機塩の 飽和溶液によって $23 \pm 1^{\circ}$ の R H $30 \%, 50$ $\%, 75 \%, 90 \%$ 各相対湿度を設定した ${ }^{99}$.

\section{5 . 吸湿水分}

上記同様各相対湿度に保存した錠剤の重量变化率より 求めた. 


\section{I 硬度試験}

\section{結果と考察}

調剤指針には錠剂の硬度は $3 \sim 7 \mathrm{~kg}$ 適当と記載され ておりわれわれが用いた試料の約 $60 \%$ がこの範囲の硬 度であった。

1）バラ鎔で保存した場合の硬度変化

錠剤は吸湿によってその硬度は図 1 亿示すように $3 つ$ の硬度变化のパターンに分かれた。

まずトルブタミドの例で示すように，乾燥剤中では硬 度が低くて， RH 30～50\% の範用で高い硬度を示し，
高湿度 R H 75\% 以上で再び硬度が 低下したものが 25 種類中10種類 $(40 \%)$ あった.つぎにジギトキシンの例 で示すように R H 60\%近くまであまり硬度が変わらず R H 75\%以上で低下したものが25種類中 6 種類 (24\%) あった，最後に塩化リゾチーム（A社）のように乾燥状 態で最も高い硬度を保ち，吸湿にしたがい硬度の低下が 見られ， RH 75\% 以上で乾燥状態の硬度に比較したと き約 $1 / 2$ 以下の硬度になったものが 25 種類中 9 種類 (36 \%)あった.

2）シールのままの状態で保存した場合の硬度変化
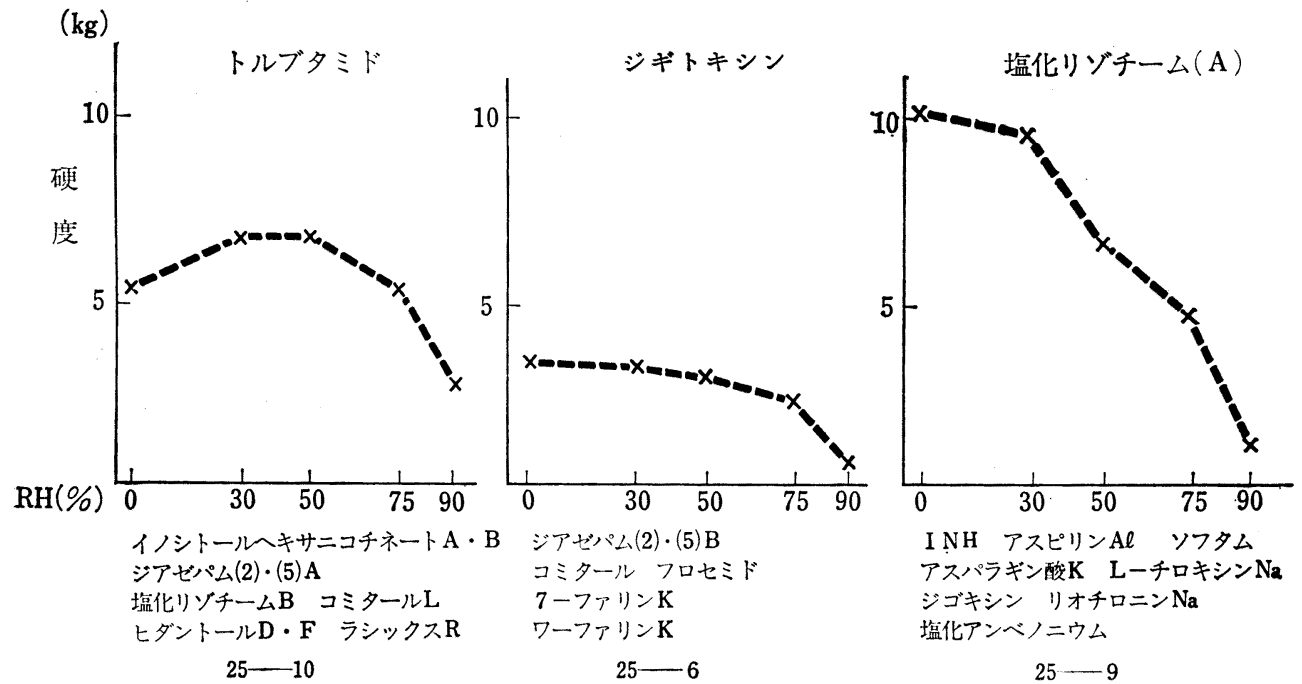

因1.バラ錠で保存したときの硬度変化のパターン

（各R H 亿14日間保存）

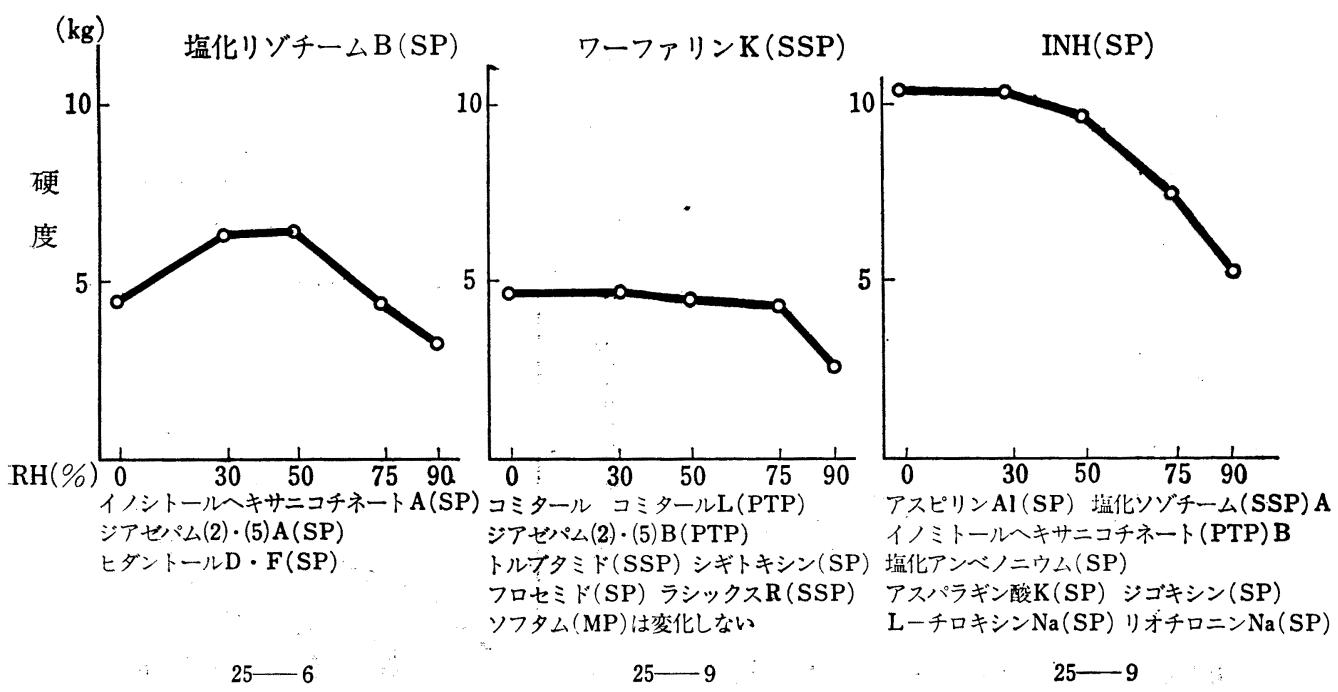

因 2、シールのままの状態で保存したときの硬度変化のパターン（各R H 亿14日間保存） 
因 2 に示すようにバラ鍰にして保存した場合と同様, 3つのパターンに分かれた．ただしメタルパックのもの はほとんど変化を認めなかった。

まず塩化リゾチーム（B社）の例で示すように, 乾燥 剂中に保存すると硬度が低下し R H 30～50\% の範囲で 高い硬度を示し， RH 75\% 以上から低下したものが 25 種類中 6 種類 $(24 \%)$, つぎにワーファリンカリウムの 例で示すよ5に R H 75\%近くまでほとんど硬度の変化 が認められず，それ以上になって低下したものが25種類 中 9 種類 ( $36 \%$ ), 最後に I N H のよに乾燥状態で最 も高い硬度を示し， R H $50 \%$ 以上から徐々に硬度が低 下したものが 25 種類中 9 種類 (36\%) あった. 因 1 , 2 を比較すると分かるように, 同一錠郕でもシールのま まの状態で保存した場合とバラ錠で保存した場合とでは 必ずしも同じ硬度変化のパターンを示さなかった。たと
えばコミタール，トルブタミド，ラシックス Rのように バラ錠で保存すると，乾燥剤中では硬度が低く， R H 30 50\%の範囲で高い硬度を示し，それ以上の R Hで再 び硬度が低下したものが，シールのままの状態で保存す ると R H 75\%近くまでほとんど变化を示さず，またイ ノシトールーキサニコチネート（B社）のように，バラ 錠で保存すると乾燥剤中で硬度が低下したが，シールの ままで保存すると乾燥状態で高い硬度を示し， R H50 \%以上から徐々に低下したものもあった。このことはシ ールが湿度の影響を防いでいるためと思われる。

3）シールによる硬度変化と吸湿水分の差

シールのままの状態とバラ錠で保存したときの硬度変 化の差と, 吸湿水分に上る重量変化率の差を， 3 種類の ものについて検討してみると，図3，4，5 亿示したよ らな变化の差を認めた。
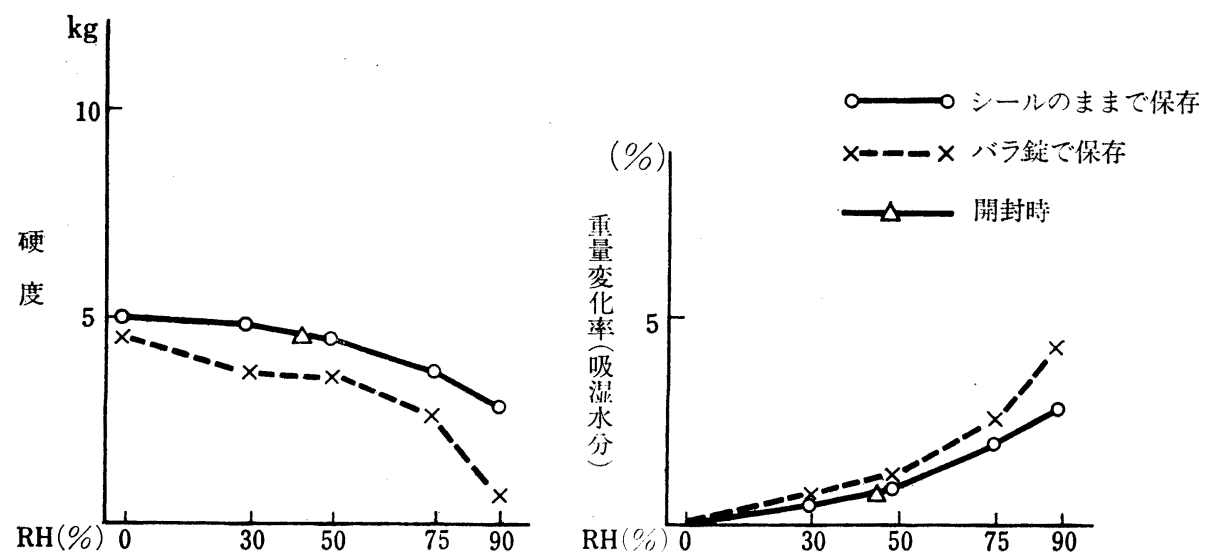

図 3、リオチロニンナトリウム
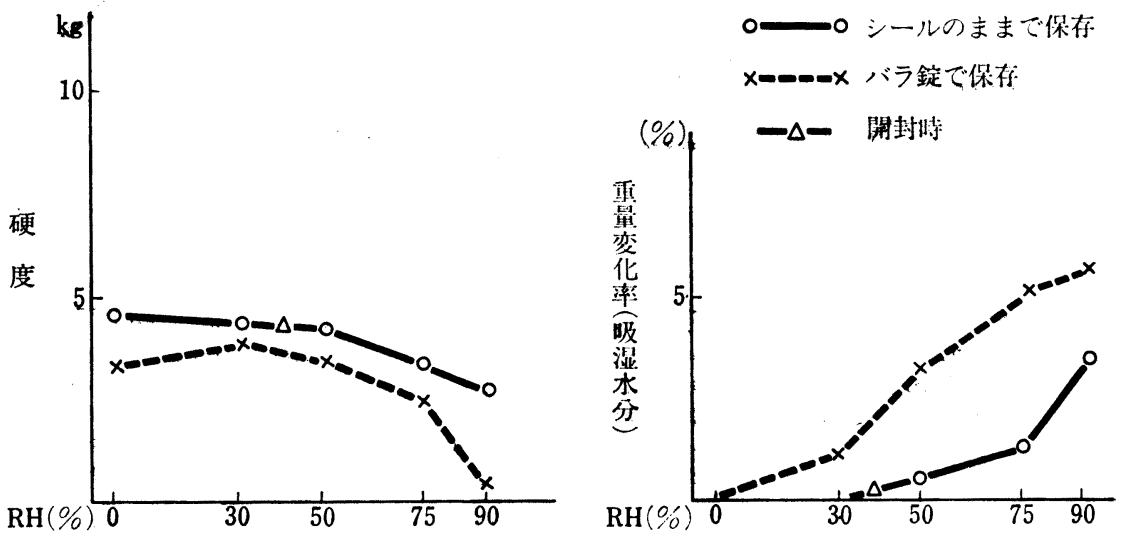

図4.ラシックスR (SSP) 

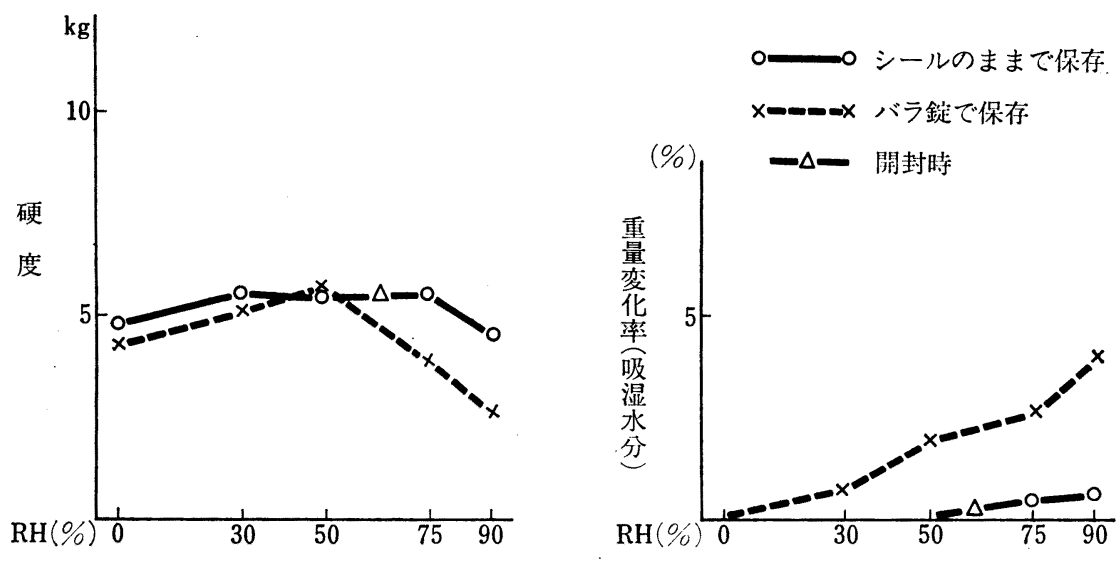

図 5・コミタールL (PTP)

シールのままの状態では多くのものが RH 75\%まで は影響が小さかったが, バラ錠で保存すると湿度の影響 を受けやすいことがわかった。

四の中で $\triangle$ 印は開封時の硬度と重量変化率を示するの である.リオチロニンナトリウム（S P ), ラシックス R（SSP）について比較してみると，シールのままで R H 90\% に保存した時の硬度がバラ錠にして R H 75\% に保存したときの硬度とほぼ同じ值を, またシールのま まで R H 75\% 保存とバラ錠の R H 50\% 保存とほぼ同
じ硬度であった.つぎに, 当院で自家シール包装してい る市販裸錠 3 種類の硬度変化打よび吸湿水分による重量 変化率について検討した. 市販の錠剤のシールは材質, 厚さ, 透湿度等は不明のものが多いが, 当院では厚さ $30 \mu$, 透湿度 (JIS-0208 試験法による) $14.5 \mathrm{~g} / \mathrm{m}^{2} / 24 \mathrm{hr}$ のポリセロ(ポリエチレントセロファン)で両面シールを 行い, そのものについての硬度変化と吸湿水分による重 量変化率の曲線を図 6，7 亿示した。（シール包装は目 黒薬品工業K K製自動シール機を使用した。）
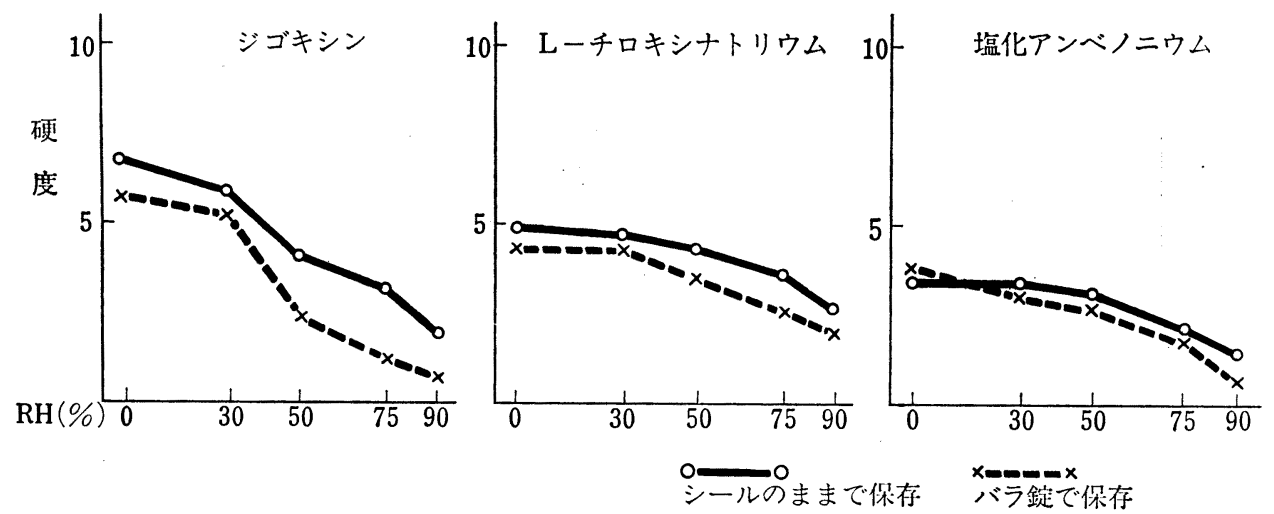

因 6. 当院でシールしている錠剤の硬度変化
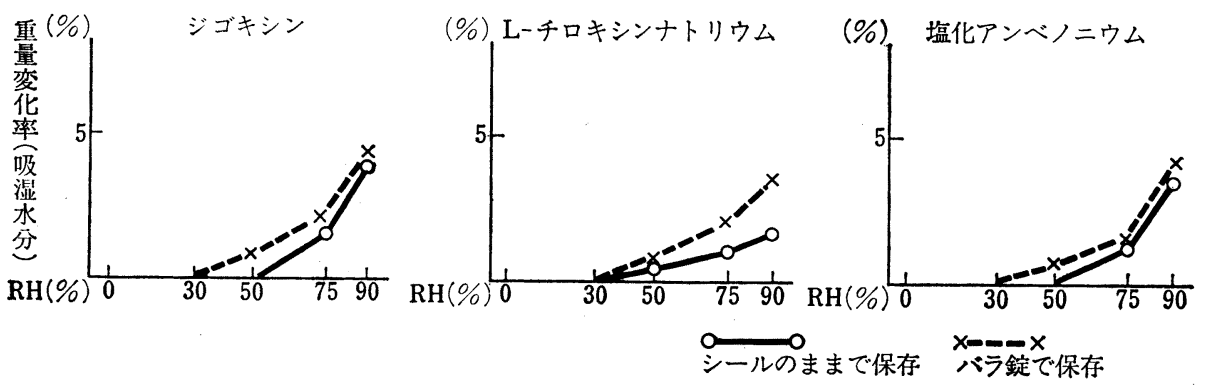

因 7. 当院でシールしている锭郕の吸湿水分による重量変化率 
ジゴキシンのように湿度の影響によって硬度の低下の 著しいものについてみた場合, バラ錠で保存すると， R H $50 \%$ 近くで乾燥状態保存のときの1/2以下の硬度にな ク, RH $75 \%$ では $1 / 3$ の硬度になり, シールのまま保 存に比較して大きく硬度が下がった。シールのままでは R H $90 \%$ 保存とバラ錠で R H $50 \%$ 保存のときの硬度 とがほぼ同じ硬度であった：Lーチロキシンナトリウム についてもシールのままで R H 90\% 保存とバラ錠で RH $75 \%$ 保存の場合とが，またシールのままでR H75 \%保存とバラ錠で R H $50 \%$ 保存とが, ほぼ同じ硬度で あった. 塩化アンベノニウムについては RH 75\% まで シールのままとバラ錠とではあまり硬度変化の差を認め なかったが, やはり RH 75\% 以上ではバラ錠の方が大 きく硬度の低下を示した. 吸湿水分による重量変化率に ついてみると， 3 種類ともバラ錠で保存すると, 硬度の 低下と反比例的に湿度による重量变化率が増大した。

4）散剂自動分包機用薬包紙を用いてシールした場合 の硬度変化と吸湿水分による重量変化率

バラ鋔で保存したとき湿度の影響を大きく受けて硬度
が著しく低下したもの 3 種類を選んで（アスパラギン酸 カリウムはフィルムコーティングであるが吸湿が大きい ので選んだ)，当院で使用している散剤用自動分包紙・ ポリグラシン紙(ポリエチレン+グラシン紙)を用いて, その防湿効果を各鏔剤について比較するため, 市販シー ルのままの状態とバラ鉃，分包紙でシールしたものとの 硬度変化扰よびその吸湿水分による重量変化率を図 8 , 9 に示した.

硬度はアスパラギン酸カリウムがバラ錠保存に比較し て, R H 50〜75\% の範囲で少しく防湿効果があるが, R H 90\% に保存したものではほとんど防湿効果がなか った.ソフタムはバラ錠でも分包紙でもほとんど同じよ らに硬度が低下した。これはンフタム錠が非常に吸湿性 が大であり，メタルパックによる完全防湿が最も安定で あることを認めた. ジアゼパム(5) (B 社) の場合は分包 紙でシールしたものが, 市販のシールのままの状態とバ ラ錠保存の場合とのほぼ中間の值を示した. 吸湿水分に よる重量変化率について比較してみると, 硬度変化に反 比例してバラ錠, 分包紙, 市販のシールのままの順に变

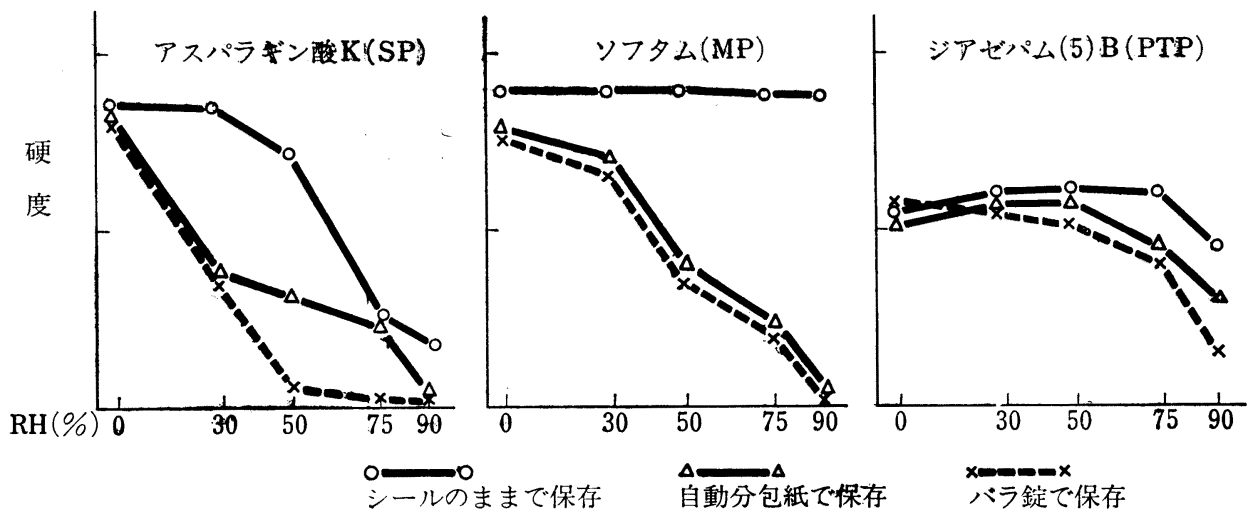

困 8.散剂用自動分包紙を用いた場合の硬度変化

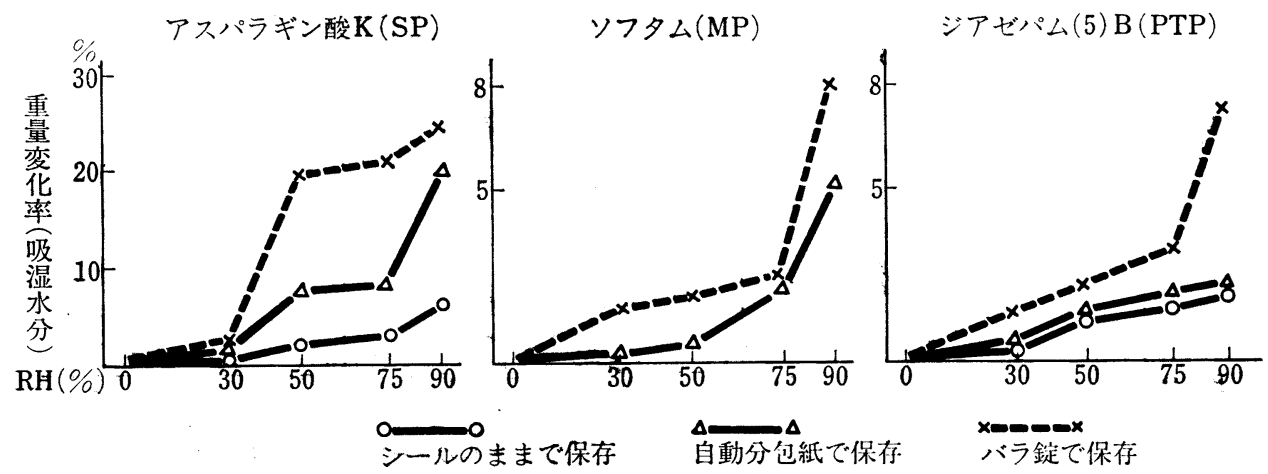

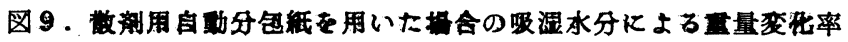


化が増大した．特にアスパラギン酸カリウムは湿度の影 響を受けやすく，ハラ錠で保存すると吸湿水分による重 量変化率が RH $50 \%$ 保存では20.4\%，RH $75 \%$ では 22.9\%，RH90\%では $25.4 \%$ までそれぞれ増加した。 同様に分包紙でシールしたものでは R H $50 \%$ 保存で $7.3 \%$, RH 75\%で 7.7\%, RH 90\%では $22.8 \%$ と,
それぞれ高湿度になるとともにやはり重量変化率は增大 したが，RH 50〜75\% の範囲の保存では多少防湿效果 があることがわかった。

\section{II 崩壊度試験}

日局 8 では「錠剤(裸錠)は $37 \pm 2 \circ$ の水で 30 分以内に 全部崩壊する」と規定している.今回の実験に使用した錠

表 1 . 崩壊時間 の分類

\begin{tabular}{|c|c|c|c|c|}
\hline 1 分以内 & $1 \sim 2$ 分 & $2 \sim 3$ 分 & $3 \sim 5$ 分 & $9 \sim 11$ 分 \\
\hline $\begin{array}{l}\mathrm{I} N \mathrm{H} \text { ソフタム } \\
\text { シアゼパム(2)(5)B } \\
\text { ジゴキシン } \\
\text { トルブタミド } \\
\text { フロセミド } \\
\text { ラシックス } \mathrm{R} \\
\text { コミタール } \mathrm{L}\end{array}$ & $\begin{array}{l}\text { アスピリンアルミ } \\
\text { ニウム L-チロ } \\
\text { キシンナトリゥム } \\
\text { 塩化アンベノニウ } \\
\text { ム コミタール } \\
\text { リオチロニンナト } \\
\text { リウム }\end{array}$ & $\mid$\begin{tabular}{c|} 
ヒダントールD \\
ヒダントールF \\
ワーファリンカリウム \\
ジアゼパム(2)A
\end{tabular} & $\begin{array}{l}\text { 塩化リゾチームA } \\
\text { 塩化リゾチーム B } \\
\text { ジアゼパム(5)A } \\
\text { ジギトキシン }\end{array}$ & $\begin{array}{l}\text { イノシトールヘキ } \\
\text { サニコチネートA } \\
\text { イノシトールヘキ } \\
\text { サニコチネートB }\end{array}$ \\
\hline
\end{tabular}

表 2 .バラ錠で保存したとき崩壊時間が変化したもの

（各 RHに14日間保存）

\begin{tabular}{|c|c|c|c|c|c|c|c|c|}
\hline \multicolumn{2}{|c|}{ 品名 $\mathrm{RH}(\%)$} & 0 & 30 & 50 & 75 & 90 & 開封時 & シール \\
\hline \multicolumn{2}{|c|}{ イノシトールヘキサ T } & $11^{\prime} 30^{\prime \prime}$ & $10^{\prime} 50^{\prime \prime}$ & $10^{\prime} 10^{\prime \prime}$ & $9^{\prime} 30^{\prime \prime}$ & $8^{\prime} 30^{\prime \prime}$ & $10^{\prime} 40^{\prime \prime}$ & \multirow{2}{*}{ P T P } \\
\hline ニコチネートB & $\mathrm{H}$ & 8.4 & 9.2 & 8.6 & 5.7 & 1.8 & 9.1 & \\
\hline \multirow{2}{*}{ 塩化リゾチームA } & $\mathrm{T}$ & $3^{\prime} 30^{\prime \prime}$ & $3^{\prime} 40^{\prime \prime}$ & $4^{\prime} 10^{\prime \prime}$ & $3^{\prime} 10^{\prime \prime}$ & $3^{\prime} 10^{\prime \prime}$ & $4^{\prime} 40^{\prime \prime}$ & \multirow{2}{*}{ S S P } \\
\hline & $\mathrm{H}$ & 10.0 & 9.5 & 6.4 & 4.8 & 1.1 & 10.2 & \\
\hline \multirow[b]{2}{*}{ 塩化リゾチームB } & $\dot{\mathrm{T}}$ & $4^{\prime} 20^{\prime \prime}$ & $4^{\prime} 20^{\prime \prime}$ & $4^{\prime} 20^{\prime \prime}$ & $4^{\prime} 00^{\prime \prime}$ & $40^{\prime \prime}$ & $4^{\prime} 10^{\prime \prime}$ & \multirow{2}{*}{ S P } \\
\hline & $\mathbf{H}$ & 3.8 & 5.5 & 5.7 & 3.3 & 0.4 & 6.3 & \\
\hline \multirow{2}{*}{ コミタール } & $\mathrm{T}$ & $1^{\prime} 50^{\prime \prime}$ & $2^{\prime} 10^{\prime \prime}$ & $2^{\prime} 20^{\prime \prime}$ & $2^{\prime} 10^{\prime \prime}$ & $40 "$ & 1'. $50^{\prime \prime}$ & \multirow{2}{*}{ PTP } \\
\hline & $\mathrm{H}$ & 2.8 & 2.5 & 2.5 & 2.5 & 1.5 & .2 .5 & \\
\hline \multirow{2}{*}{ ジアゼパム(2)A } & $\mathrm{T}$ & $1^{\prime} 50^{\prime \prime}$ & $2^{\prime} 00^{\prime \prime}$ & $1^{\prime} 50^{\prime \prime}$ & $1^{\prime} 20^{\prime \prime}$ & $10^{\prime \prime}$ & $2^{\prime} 00^{\prime \prime}$ & \multirow{2}{*}{ S P } \\
\hline & $\mathbf{H}$ & 5.5 & 6.0 & 5.0 & 2.9 & 1.9 & 5.7 & \\
\hline \multirow{2}{*}{ ジアゼパム(5)A } & $\mathrm{T}$ & $3^{\prime} 40^{\prime \prime}$ & $4^{\prime} 00^{\prime \prime}$ & $3^{\prime} 50^{\prime \prime}$ & $3^{\prime} 20^{\prime \prime}$ & $1^{\prime} 20^{\prime \prime}$ & $3^{\prime} 50^{\prime \prime}$ & \multirow{2}{*}{ S P } \\
\hline & $\mathrm{H}$ & 7.5 & 9.9 & 8.7 & 6.3 & 2.0 & 9.9 & \\
\hline \multirow{2}{*}{ ジアゼパム(5)B } & $\mathrm{T}$ & $5^{\prime} 55^{\prime \prime}$ & $50^{\prime \prime}$ & $55^{\prime \prime}$ & $20 "$ & $10^{\prime \prime}$ & $50^{\prime \prime}$ & \multirow{2}{*}{ P T P } \\
\hline & $\mathrm{H}$ & 5.7 & 5.7 & 5.2 & 4.1 & 1.6 & 6.2 & \\
\hline \multirow{2}{*}{ ジギトキシン } & $\mathrm{T}$ & $4^{\prime} 30^{\prime \prime}$ & $4^{\prime} 40^{\prime \prime}$ & $4^{\prime} 40^{\prime \prime}$ & $4^{\prime} 20^{\prime \prime}$ & $30^{\prime \prime}$ & $4^{\prime} 40^{\prime \prime}$ & \multirow{2}{*}{ S P } \\
\hline & $\mathrm{H}$ & 3.2 & 3.1 & 2.9 & 2.3 & 0.5 & 3.1 & \\
\hline \multirow{2}{*}{ ヒダントールD } & $\mathrm{T}$ & $2^{\prime} 30^{\prime \prime}$ & $2^{\prime} 30^{\prime \prime}$ & $2^{\prime} 30^{\prime \prime}$ & $2^{\prime} 30^{\prime \prime}$ & I' $30^{\prime \prime}$ & $2^{\prime} 40^{\prime \prime}$ & \multirow{2}{*}{$\mathrm{SP}$} \\
\hline & $\mathrm{H}$ & 3.8 & 5.1 & 4.5 & 2.7 & 0.2 & 4.3 & \\
\hline \multirow{2}{*}{ リオチロニンNa } & $\mathrm{T}$ & $1^{\prime} 10^{\prime \prime}$ & $1^{\prime} 00^{\prime \prime}$ & $1^{\prime} 10^{\prime \prime}$ & $40^{\prime \prime}$ & $20^{\circ}$ & $1^{\prime} 10^{\prime \prime}$ & \multirow{2}{*}{ S P } \\
\hline & $\mathbf{H}$ & 4.4 & 3.7 & 3.5 & 2.6 & 0.5 & 4.6 & \\
\hline
\end{tabular}

$\mathrm{T}$ ：崩壊時間 $\mathrm{H}$ ：硬度 $(\mathrm{kg})$ 
剤 24 種類のうち,イノシトールヘキサニコチネート（B 社)を除いた他の全種類が10分以内の崩壊時間であった.

1）崩壊時間の分類

表 1 に 24 種類の銫剤の崩壊時間による分類を示した。

1 分以内に崩壊したものが 24 種類中 9 種類あり， 1 2 分の範囲で崩壊したものが 24 種類中 5 種類, $2 \sim 3$ 分 の範囲で崩壊したものが24種類中 4 種類, $3 \sim 5$ 分の範 囲で崩壊したものが 24 種類中 4 種類， 9 〜 11 分の範囲 で崩壊したものが24種類中 2 種類であり，まとめると約 $90 \%$ が 5 分以内で崩壊した.

2) 崩壊時間の変化

表 2 にバラ錠で各相対湿度に14日間保存したとき，開 封時に比較して崩壊時間の変化したものを示し，その各 相対湿度に打ける硬度も示した。

表 2 に示したように高湿度 R H 75\% 以上になるとコ ミタールを除いた他のすべてのものが崩壊時間が短くな り， R H 90\% 保存でほとんどのものは崩壊時間が短縮 された。 また硬度は湿度による影響が顕著で，高湿度に なると大きく低下することがわかった，また開封時にお ける崩壊時間はすべてのものが R H 30～50\%の範团の 保存品の崩壊時間と一致した.
表 3 にシールのままの状態で保存した場合に崩壊時間 の変化したものを示した.

これを見るとバラ錠で保存した場合に比較して, シー ルのままの状態では変化したものが少なく，崩壊時間の 変化の差も僅かであった. この場合も保存が高湿度 R $\mathrm{H} 75 \%$ 以上になると, 塩化リゾチーム（B社）以外は 若干の崩壊時間の短縮を認め, リオチロニンナトリウム では1/2の崩壊時間になった．R H 90\% 保存ではすべて に短縮を認めたが，ジアゼパム (2)(5)（A社）は約 $1 / 2 の$ 崩壊時間になった。このようにシールのままの状態で保 存した場合も，硬度は崩壊時間に比較して顕著な経日変 化を示すことがわかった.

表 1 に示した崩壊時間（開封時）による分類のらち， 1 分以内に崩壊したものについては崩壊時間が短いの で，その吸湿による変化の差を認めることができなかっ た. 1 〜分の範囲ではリオチロニンナトリウム， 2 3 分の範囲ではジアぜパム (2) ( $\mathrm{A}$ 社)，3〜 5 分の範囲 では塩化リゾチーム（A・B社)，ジアゼパム (5) (A 社), ジギトキシンの 4 種類, 9 〜1分の範囲ではイ シトールヘキサニコチネート（B社）が，いずれも湿度 の影響を受けて崩壊時間に変化を生じた。

表 3 .シールのままの状態で保存したとき崩壊時間が変化したもの

（各 RHに14日間保存）

\begin{tabular}{|c|c|c|c|c|c|c|c|c|}
\hline \multicolumn{2}{|c|}{ 品名 $\mathrm{RH}(\%)$} & 0 & 30 & 50 & 75 & 90 & 開封時 & シール \\
\hline \multicolumn{2}{|c|}{ イノシトールヘキサ T } & $10^{\prime} 30^{\prime \prime}$ & $10^{\prime} 30^{\prime \prime}$ & $10^{\prime} 20^{\prime \prime}$ & $9^{\prime} 30^{\prime \prime}$ & $9^{\prime} 00^{\prime \prime}$ & $10^{\prime} 40^{\prime \prime}$ & \multirow{2}{*}{ P T P } \\
\hline ニコチネートB & $\mathrm{H}$ & 9.1 & 9.3 & 9.0 & 6.7 & 4.7 & 9.1 & \\
\hline \multirow{2}{*}{ 塩化リゾチームA } & $\mathrm{T}$ & $4^{\prime} 20^{\prime \prime}$ & $4^{\prime} 20^{\prime \prime}$ & $4^{\prime} 20^{\prime \prime}$ & $3^{\prime} 20^{\prime \prime}$ & $3^{\prime} 30^{\prime \prime}$ & $4^{\prime} 40^{\prime \prime}$ & \multirow{2}{*}{ S S P } \\
\hline & $\mathrm{H}$ & 10.5 & 9.8 & 8.6 & 8.0 & 4.1 & 10.2 & \\
\hline \multirow{2}{*}{ 塩化リゾチーム B } & $\mathrm{T}$ & $4^{\prime} .10^{\prime \prime}$ & $4^{\prime} 10^{\prime \prime}$ & $4^{\prime} 10^{n}$ & $4^{\prime} 10^{\prime \prime}$ & $3^{\prime} 30^{\prime \prime}$ & $4^{\prime} 10^{\prime \prime}$ & \multirow{2}{*}{ S P } \\
\hline & $\mathrm{H}$ & 4.3 & 5.6 & 6.4 & 4.3 & 3.2 & 6.3 & \\
\hline \multirow{2}{*}{ ジアゼパム(2)A } & $\mathrm{T}$ & $2^{\prime} 10^{\prime \prime}$ & $2^{\prime} 10^{\prime \prime}$ & $2^{\prime} 10^{\prime \prime}$ & $1^{\prime} 40^{\prime \prime}$ & $1^{\prime} 20^{\prime \prime}$ & $2^{\prime} 00^{\prime \prime}$ & \multirow{2}{*}{ S P } \\
\hline & $\mathrm{H}$ & 5.8 & 5.9 & 5.4 & 4.6 & 3.5 & 5.7 & \\
\hline \multirow{2}{*}{ ジアゼパム(5)A } & $\mathrm{T}$ & $4^{\prime} 00^{\prime \prime}$ & $4^{\prime} 00^{\prime \prime}$ & $4^{\prime} .00^{\prime \prime}$ & $3^{\prime} 20^{\prime \prime}$ & $2^{\prime} \cdot 10^{\prime \prime}$ & $3^{\prime} 50^{\prime \prime}$ & \multirow{2}{*}{ S P } \\
\hline & $\mathrm{H}$ & 8.2 & 9.9 & 9.3 & 8.3 & 6.5 & 9.9 & \\
\hline \multirow{2}{*}{ ジギトキシン } & $\mathrm{T}$ & $4^{\prime} 30^{\prime \prime}$ & $4^{\prime} 40^{\prime \prime}$ & $4^{\prime} 20^{\prime \prime}$ & $4^{\prime} 10^{\prime \prime}$ & $\mathbf{2}^{\prime} 50^{\prime \prime}$ & $4^{\prime} 40^{\prime \prime}$ & \multirow{2}{*}{$\mathrm{S} P$} \\
\hline & $\mathrm{H}$ & 3.3 & 3.9 & 3.0 & 2.7 & 2.8 & 3.1 & \\
\hline \multirow{2}{*}{ リオチロニン Na } & $\mathrm{T}$ & $1^{\prime} 20^{\prime \prime}$ & $1^{\prime} 10^{\prime \prime}$ & $1^{\prime} 05^{\prime \prime}$ & $40^{\prime \prime}$ & $35^{\prime \prime}$ & $1^{\prime} 10^{\prime \prime}$ & \multirow{2}{*}{ S P } \\
\hline & $\mathbf{H}$ & 4.9 & 4.7 & 4.5 & 3.5 & 2.7 & 4.6 & \\
\hline
\end{tabular}


結

論

裸錠の硬度は保存条件，すなわら湿度の影響を受けや すく，とくにパラ錠で保存した場合，相対湿度 $75 \%$ 以上 になると一般に大きく低下した，乙かし乾燥剤中に保存 した場合に，かえって硬度の低下を示したものが若干あ った。

崩壊度は汪とえど10分以内であったが，高湿度になる と一部に崩壊時間の短縮を認めたものもあった．硬度と 崩壞度との関連性についてみた場合, 硬度は湿度によっ て顕著な経日変化を認め心が，崩壊度は相対湿度 $90 \%$ ま ではほとんど変化を認めなかった。な抗これら錠剤の吸 湿による硬度・崩壞度の変化が, 溶出試験あるいは吸収 にどのような影響を扣よぼすかについてもさらに検討を 加宎たい。
参 考 文 献

1）奥村一忠, 北沢正康, 笠野俊彦, 長谷川高明, 中 埜末春, 高取吉太郎 : 日本薬学会第95年会講演要 旨集，西宮，P. 198 (1975).

2）客井宜之，奥田昭雄，大島考一，高杉益充：日本 薬学会第95年会講演要旨集, 西宮, P.198 (1975).

3) 弓岡栄三郎, 今里 雄, 相良弘隆: 薬剂学, 24 , 106 (1964).

4) 弓岡栄三郎, 幸田市郎, 牧田浩和: 薬剂学, 26 , 127 (1966).

5）山田博司: 薬剤学, 20, 190 (1960).

6）前川秀幸, 坂本照男, 佐藤文雄 : 薬剛学, 21 , 155 (1961).

7) 梅沢 修, 岩間考敏, 山本幸子: 薬剤学, 36, 別 冊, P. 51 (1976).

8) 北沢式文 : 日本薬剤師会雑誌，28，117 (1976).

9) Merck Index, Eight Edition, P.1143.

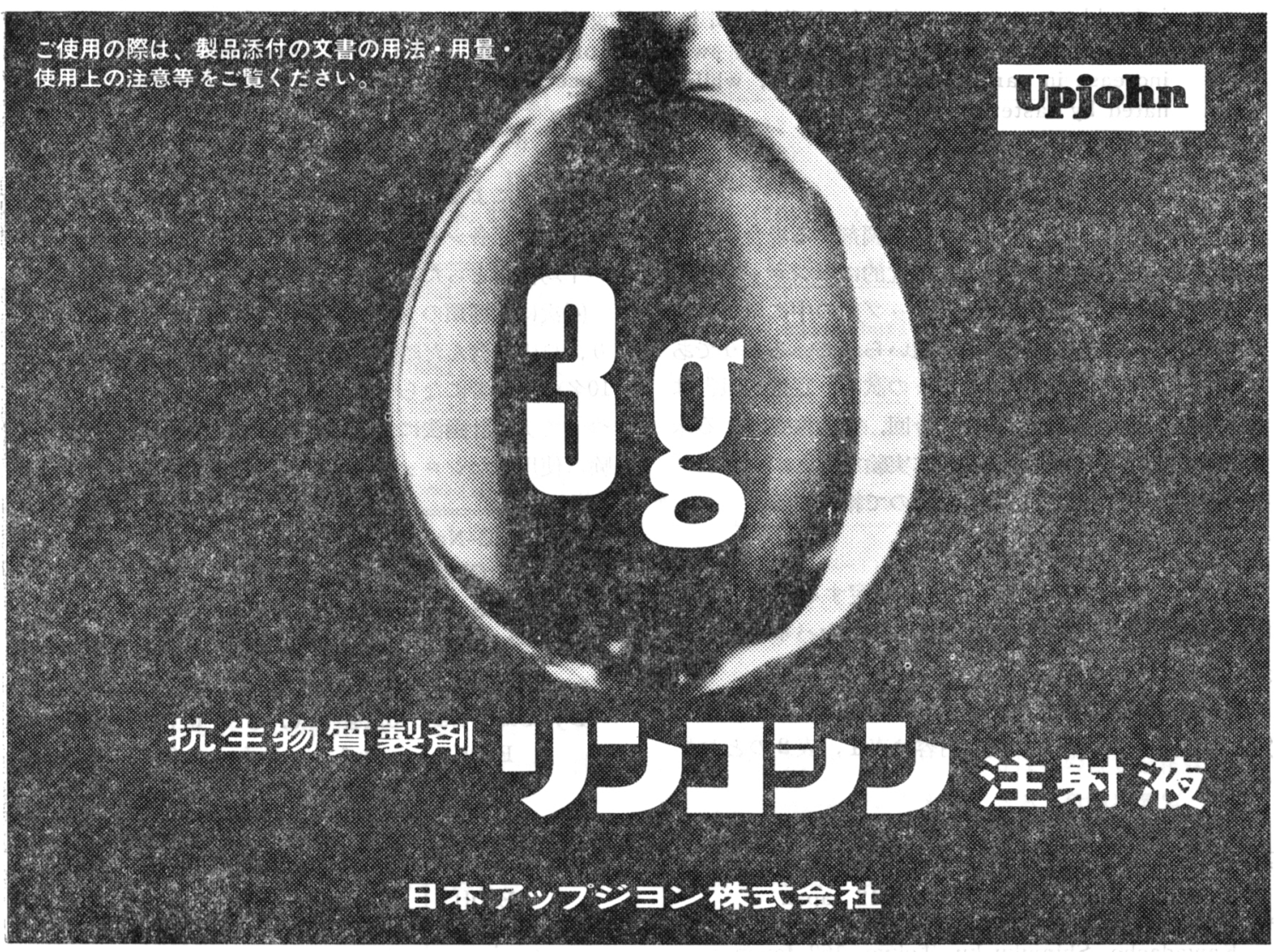

